\title{
EKSPERIMENTASI MODEL PEMBELAJARAN \\ KOOPERATIF TIPE JIGSAW DAN GROUP INVESTIGATION (GI) PADA PEMBELAJARAN DIMENSI TIGA SISWA KELAS $X$ SMA NEGERI SE-KABUPATEN WONOGIRI DITINJAU DARI TINGKAT KECERDASAN EMOSIONAL TAHUN PELAJARAN 2012/2013
}

\author{
Tarmo $^{1}$, Riyadi $^{2}$, Imam Sujadi $^{3}$ \\ ${ }^{1,2,3}$ Prodi Magister Pendidikan Matematika, PPs Universitas Sebelas Maret Surakarta
}

\begin{abstract}
The objectives of this research were to investigate: (1) which one providing better learning achievement, the Jigsaw learning model, GI or direct instruction; 2) which one having better learning achievement, the students with high, medium or low emotional quotient (EQ); 3) in each category of $\mathrm{EQ}$, which one providing better learning achievement, the Jigsaw, GI or direct instruction; 4) in each type of the learning model, which one having better learning achievement, the students with high, medium or low EQ. This research was a quasi-experimental research using factorial design of $3 \times 3$. The population of the research were all students of the Public Senior High Schools in Wonogiri Regency. The samples were chosen by using stratified cluster random sampling. The samples of the research were tenth grade students of SMA N 1 Wonogiri, SMA N 2 Wonogiri, and SMA N 1 Sidoharjo. In collecting the data, the instruments used were test and questionnaire. The technique of analyzing the data was unbalanced two-ways Anova. The results of the research are as follows: (1) the Jigsaw result in a better learning achievement than GI and direct instruction, the GI result in a better learning achievement than direct instruction; (2) the students with the high EQ result in a better learning achievement than the students with the medium or low EQ, the students with the medium EQ result in a better learning achievement than the students with the low EQ; (3) the students with the low EQ, the Jigsaw, GI and direct instruction have the same learning achievement; the students with the medium EQ, the Jigsaw and GI result in the same learning achievement, the GI learning model and direct instruction result in the same learning achievement and the Jigsaw result in a better learning achievement than direct instruction; the students with the high EQ the Jigsaw and GI result in the same learning achievement, and both result in a better learning achievement than the direct instruction; (4) in the Jigsaw and GI, the students with the low and medium EQ result in the same learning achievement, but students with the high EQ result in a better learning achievement than the students with the low or medium EQ, in the direct instruction, the students with the low, medium and high EQ result in the same learning achievement.
\end{abstract}

Key words: learning model, Jigsaw, GI, emotional quotient.

\section{PENDAHULUAN}

Matematika merupakan ilmu dasar (basic science) yang berkembang pesat baik materi maupun kegunaannya di dunia ilmu pengetahuan dan teknologi. Namun ironisnya kualitas pendidikan khususnya mata pelajaran matematika di Indonesia masih rendah. Berdasarkan data BNSP diketahui bahwa untuk Kabupaten Wonogiri nilai rata-rata UN SMA Tahun 2011/2012 untuk mata pelajaran matematika masih rendah, yaitu 6,32 dan persentase penguasaan materi dimensi tiga sangat rendah jika dibanding dengan materi lainnya. Hal ini dapat dilihat dari contoh berikut : logika matematika $69,23 \%$, sistem persamaan linear $76,27 \%$, statistika $88,76 \%$, limit fungsi $53,25 \%$, matriks $67,83 \%$ dan 
dimensi tiga 44,52\% (sumber : Puspendik Balitbang Kemdikbud BNSP 2012). Data-data tersebut menunjukkan bahwa masih banyak siswa yang mengalami masalah dalam pembelajaran matematika, khususnya pada materi dimensi tiga, sehingga perlu dicari solusi untuk mengatasinya.

Pada umumnya guru matematika cenderung lebih mendominasi pembelajaran dan siswa kurang aktif dalam proses belajar mengajar. Hal ini tentunya akan berdampak pada pencapaian hasil belajar matematika siswa. Pembelajaran matematika yang hanya berpusat pada guru masih dilaksanakan di sekolah-sekolah, sehinggga kesempatan siswa untuk belajar aktif sangat terbatas. Biasanya guru hanya memberikan definisi, teorema, contoh-contoh dan latihan, dan siswa pasif. Keadaan semacam ini sangat mengurangi tanggung jawab siswa atas tugas belajarnya. Siswa seharusnya dituntut untuk mengonstruksi, menemukan dan mengembangkan kemampuannya serta dapat mengungkapkan dalam bahasanya sendiri tentang apa yang diterima dan diolah selama pembelajaran berlangsung.

Guru mempunyai peranan cukup penting untuk mengadakan perubahan. Proses pembelajaran di kelas menuntut perubahan paradigma pembelajaran . Aktivitas pembelajaran perlu dihindari yang sifatnya mekanistik belaka, karena pembelajaran mekanistik kurang bermakna, sehingga perlu pembelajaran yang melibatkan siswa secara aktif. Pembelajaran kooperatif merupakan salah satu pembelajaran yang melibatkan siswa secara aktif. Dalam pembelajaran kooperatif, siswa terlibat dalam diskusi, memecahkan masalah bersama, bekerja sama, mendengarkan pendapat siswa yang lain bahkan menyampaikan atau mempresentasikan hasil dari kerjasama kelompok.

Penelitian tentang pembelajaran kooperatif telah dilakukan Ballantine dan Larres (2007) menyatakan bahwa "students found the cooperative learning approach beneficial in developing their generic skills". Ini menunjukkan bahwa pembelajaran kooperatif bermanfaat untuk mengembangkan kemampuan umum para siswa. Ruang kelas merupakan suatu tempat yang sangat baik untuk kegiatan pembelajaran kooperatif. Para siswa dapat diberi kesempatan bekerja dalam kelompok-kelompok kecil untuk menyelesaikan atau memecahkan suatu masalah secara bersama. Para siswa juga diberi kesempatan untuk mendiskusikan masalah, menentukan strategi pemecahannya, dan menghubungkan masalah tersebut dengan masalah lain yang telah dapat diselesaikan sebelumnya.

Model pembelajaran kooperatif yang dapat digunakan pada pembelajaran matematika diantaranya model pembelajaran Jigsaw dan GI. Jigsaw merupakan salah satu model belajar kooperatif formal. Belajar kooperatif formal merupakan bentuk belajar kooperatif yang melibatkan siswa untuk bekerja sama dalam satu periode pelajaran 
hingga beberapa minggu untuk mencapai tujuan belajar. Slavin (2009: 237) menjelaskan bahwa dalam pembelajaran tipe Jigsaw, para siswa bekerja dalam tim yang heterogen. Para siswa tersebut diberikan tugas untuk membaca beberapa bab atau unit, dan diberikan "lembar ahli" yang terdiri atas topik-topik yang berbeda yang harus menjadi fokus perhatian masing-masing anggota tim saat mereka membaca. Setelah semua anak selesai membaca, siswa-siswa dari tim yang berbeda yang mempunyai fokus topik yang sama bertemu dalam "kelompok ahli" untuk mendiskusikan topik mereka sekitar tiga puluh menit. Para ahli tersebut kemudian kembali kepada tim mereka dan secara bergantian mengajari teman satu timnya mengenai topik mereka. Yang terakhir para siswa menerima penilaian yang mencakup seluruh topik, dan perkembangan skor individu akan menjadi skor tim. Jigsaw merupakan teknik terbaik dalam proses pembelajaran. Hal ini disebabkan dalam model pembelajaran Jigsaw siswa secara individual berkembang dan berbagi kemampuan dalam bermacam aspek kerja yang berbeda.

Pembelajaran kooperatif yang lain yaitu GI sebagai suatu model pembelajaran kooperatif yang melibatkan siswa sejak dari perencanaan, baik dalam menentukan topik maupun cara untuk mempelajarinya melalui investigasi. Sehingga model pembelajaran ini menuntut keaktifan dari siswa sebagai subjek sekaligus objek pendidikan dan pengajaran. Siswa tidak hanya sebagai objek yang diam tanpa ada upaya dari diri sendiri untuk bisa bagaimana seharusnya dia belajar, bukan bagaimana menulis pelajaran matematika. Selain itu model GI menuntut para siswa untuk memiliki kemampuan yang baik dalam berkomunikasi maupun dalam keterampilan proses kelompok (group process skills). Sugiyanto (2008: 44) menjelaskan bahwa dasar-dasar model GI dirancang oleh Herbert Thelen, selanjutnya diperluas dan diperbaiki oleh Sharn dan kawan-kawan. Para guru yang menggunakan model GI umumnya membagi kelas menjadi beberapa kelompok yang beranggotakan 4 hingga 5 siswa dengan karakteristik yang heterogen. Pembagian kelompok dapat juga didasarkan atas dasar kesenangan berteman atau kesamaan minat terhadap suatu topik tertentu. Para siswa memilih topik yang ingin dipelajari mengikuti investigasi mendalam terhadap berbagai subtopik yang telah dipilih, kemudian menyiapkan dan menyajikan suatu laporan di depan kelas secara keseluruhan.

Tan et al, (2007) dalam penelitiannya menyimpulkan bahwa: "Students in GIand in whole-class instruction advanced to the same extent over the course of the experiment. Neither method was more effective academically than the other method."

Penelitian ini menunjukkan bahwa siswa yang berada pada kelas model pembelajaran kooperatif GI lebih baik jika dibandingkan dengan pembelajaran tradisional. 
Faktor lain yang berpengaruh terhadap prestasi belajar siswa adalah kecerdasan emosional (Emotional Intellegence). Emotional Intellegence sangat berpengaruh dalam proses dan keberhasilan belajar. Hal ini karena belajar tidaklah semata-mata persoalan intelektual, tetapi juga emosional. Belajar tidak hanya sekedar interaksi dengan sumber dan bahan ajar, tetapi juga melibatkan hubungan manusiawi antara sesama siswa dan antara guru dengan siswa. Keberhasilan seseorang dalam kehidupan tidak hanya ditentukan oleh Intellegence Quotient (IQ), tetapi juga oleh kecerdasan emosional. Intelektualitas tidak dapat bekerja sebaik-baiknya tanpa kecerdasan emosional. Goleman (2009:44) menyatakan bahwa setinggi-tingginya IQ menyumbang kira-kira hanya 20 persen bagi faktor-faktor yang menentukan sukses dalam hidup, 80 persen diisi oleh kekuatan-kekuatan lain, diantaranya ditentukan kelas sosial dan nasib baik. Richard dan Charles dalam bukunya The Bell Curve menyatakan bahwa kecerdasan emosional adalah kemampuan memotivasi diri sendiri dan bertahan menghadapi frustasi; mengendalikan dorongan hati dan tidak melebih-lebihkan kesenangan; mengatur suasana hati dan menjaga agar beban stress tidak melumpuhkan kemampuan berpikir, berempati dan berdoa.

Untuk mengatasi masalah siswa dalam pembelajaran matematika di kabupaten Wonogiri, khususnya pada materi dimensi tiga peneliti mencoba untuk melakukan penelitian sehingga diharapkan dari penelitian ini akan mampu mengetahui pengaruh penggunaan model pembelajaran Jigsaw, GI dan tingkat kecerdasan emosional terhadap prestasi belajar matematika khususnya pada materi dimensi tiga.

Berdasarkan uraian yang dikemukakan tersebut, tujuan yang hendak dicapai dalam penelitian ini adalah untuk mengetahui: (1) model pembelajaran kooperatif manakah yang dapat menghasilkan prestasi belajar yang lebih baik, model pembelajaran Jigsaw, GI atau langsung; (2) manakah yang mempunyai prestasi belajar yang lebih baik, siswa dengan kecerdasan emosional tinggi, sedang atau rendah; (3) pada masing-masing tingkat kecerdasan emosional, manakah yang menghasilkan prestasi belajar yang lebih baik, model pembelajaran Jigsaw, GI atau langsung; (4) pada masing-masing model pembelajaran, manakah yang mempunyai prestasi belajar yang lebih baik, tingkat kecerdasan emosional tinggi, sedang atau rendah.

\section{METODE PENELITIAN}

Penelitian ini dilaksanakan di SMA Negeri se-Kabupaten Wonogiri. Waktu penelitian dilaksanakan selama 6 bulan yaitu bulan Januari 2013 sampai dengan bulan Juni 2013. Penelitian ini merupakan penelitian eksperimental semu dengan desain faktorial 3x3. Analisis data dilakukan dengan Anava dua jalan sel tak sama dengan taraf 
signifikansi 5\%. Populasi penelitian adalah seluruh siswa kelas X Semester II SMA Negeri se-Kabupaten Wonogiri tahun pelajaran 2012/2013. Sampel penelitian ini adalah SMA N 1 Wonogiri, SMA N 2 Wonogiri, dan SMA N 1 Sidoharjo. Dari masing-masing sekolah diambil tiga kelas secara acak, masing-masing satu kelas eksperimen model pembelajaran Jigsaw, satu kelas eksperimen model pembelajaran GI dan satu kelas kontrol model pembelajaran langsung. Adapun ukuran sampel pada penelitian ini adalah 264 siswa.

Uji normalitas untuk data kemampuan awal menggunakan metode Liliefors dan diperoleh hasil bahwa ketiga kelompok berasal dari populasi yang berdistribusi normal. Hal ini dapat dilihat pada Tabel 1.

\section{Tabel 1 Rangkuman Hasil Uji Normalitas Data Kemampuan Awal}

\begin{tabular}{cccc}
\hline Pembelajaran & $\mathrm{L}_{\text {obs }}$ & $\mathrm{L}_{0,05 ; n}$ & Keputusan Uji \\
\hline Jigsaw & 0,054 & 0,095 & $\mathrm{H}_{0}$ tidak ditolak \\
GI & 0,070 & 0,094 & $\mathrm{H}_{0}$ tidak ditolak \\
Langsung & 0.054 & 0,094 & $\mathrm{H}_{0}$ tidak ditolak \\
\hline
\end{tabular}

Uji homogenitas untuk kemampuan awal ini menggunakan uji Bartlett dengan tingkat signifikansi 5\%. Hasil dari uji homogenitas dengan nilai $\mathrm{k}=3$ diperoleh nilai $\chi_{o b s}^{2}=2,10$ dan $\chi_{0,05 ; k-1}^{2}=5,99, \mathrm{DK}=\left\{\chi^{2} \mid \chi^{2}>5,99\right\}, \chi_{o b s}^{2} \notin \mathrm{DK}$ sehingga $\mathrm{H}_{0}$ tidak ditolak. Oleh karena itu, dapat disimpulkan bahwa variansi-variansi dari tiga populasi homogen. Uji keseimbangan rataan kemampuan awal menggunakan anava satu jalan dengan sel tak sama, diperoleh nilai statistik uji $F_{\text {obs }}=0,082$ dan $F_{\text {tabel }}$ pada taraf signifikasi $5 \%$ adalah 3,15 , berarti $\mathrm{F}_{\mathrm{obs}}=0,082 \notin \mathrm{DK}=\{\mathrm{F} \mid \mathrm{F}>3,15\}$, sehingga $\mathrm{H}_{0}$ tidak ditolak. Oleh karena itu, dapat disimpulkan bahwa ketiga kelompok model pembelajaran berasal dari populasi yang berkemampuan awal sama.

Teknik pengumpulan data adalah teknik: (1) tes; (2) dokumentasi; (3) angket. Instrumen penelitian terdiri atas: (1) tes prestasi belajar matematika; (2) angket kecerdasan emosional. Variabel terikat adalah prestasi belajar matematika pada materi dimensi tiga, sedangkan variabel bebasnya model pembelajaran yang terdiri dari model pembelajaran Jigsaw pada kelas eksperimen 1, model pembelajaran GI pada eksperimen 2 dan model pembelajaran langsung pada kelas kontrol. Variabel yang lain adalah kecerdasan emosional dengan kategori rendah, sedang dan tinggi.

Sebelum angket kecerdasan emosional dan tes prestasi dimensi tiga digunakan, terlebih dahulu dilakukan uji coba instrumen. Pada uji coba tes prestasi belajar dimensi tiga diuji tentang validitas, konsistensi/ daya beda, reliabilitas dan tingkat kesukaran. Sedangkan uji coba instrumen angket kecerdasan emosional diuji tentang validitas, konsistensi dan reliabilitas. Hasil uji coba instrumen diperoleh nilai uji reliabilitas dengan 
model KR-20 pada tes prestasi belajar 0,74 dan nilai uji reliabilitas angket kecerdasan emosional adalah 0,92 .

\section{HASIL PENELITIAN DAN PEMBAHASAN.}

Rangkuman hasil perhitungan analisis variansi dua jalan dengan sel tak sama untuk prestasi belajar setelah dilaksanakan eksperimen disajikan dalam Tabel 2.

Tabel 2. Rangkuman Hasil Uji Hipotesis

\begin{tabular}{lcccccc}
\hline \multicolumn{1}{c}{ Sumber variansi } & $\mathrm{JK}$ & $\mathrm{db}$ & $\mathrm{RK}$ & $\mathrm{F}_{\mathrm{obs}}$ & $\mathrm{F}_{\text {tabel }}$ & Keputusan Uji \\
\hline Model & 6320,58 & 2 & 3160,29 & 42,36 & 3,07 & $\mathrm{H}_{0 \mathrm{~A}}$ ditolak \\
Pembelajaran (A) & & & & & & \\
Kecerdasan & 8743,02 & 2 & 4371,51 & 58,60 & 3,07 & $\mathrm{H}_{0 \mathrm{~B}}$ ditolak \\
Emosional (B) & 1286,51 & 4 & 321,63 & 4,31 & 2,45 & $\mathrm{H}_{0 \mathrm{AB}}$ ditolak \\
Interaksi (AB) & 19022,70 & 263 & 74,59 & - & - & - \\
Galat & 35272,80 & & - & - & - & - \\
Total &
\end{tabular}

Dari rangkuman hasil perhitungan anava ditunjukkan bahwa $\mathrm{H}_{0 \mathrm{~A}}, \mathrm{H}_{0 \mathrm{~B}}$ dan $\mathrm{H}_{0 \mathrm{AB}}$ ditolak, maka perlu dihitung rataan marginal masing-masing baris, rataan marginal masing-masing kolom dan rataan masing-masing sel yang disajikan pada Tabel 3.

Tabel 3. Rataan Marginal dan Rataan Masing-Masing Sel

\begin{tabular}{ccccc}
\hline Model Pembelajaran & Rendah & Sedang & Tinggi & Rataan Marginal \\
\hline Jigsaw & 58,45 & 66,07 & 77,50 & 67,21 \\
GI & 54,92 & 59,65 & 70,97 & 62,70 \\
Langsung & 53,00 & 53,52 & 59,41 & 55,16 \\
Rataan Marginal & 55,52 & 59,54 & 69,52 & \\
\hline
\end{tabular}

Berdasarkan hasil analisis variansi dua jalan dengan sel tak sama pada Tabel 2, untuk efek utama faktor $\mathrm{A}$ (model pembelajaran) diperoleh nilai statistik uji $\mathrm{F}_{\mathrm{A}}=42,36$ dan $\mathrm{F}_{\alpha}=\mathrm{F}_{0,05 ; 2 ; 245}=3,07$, berarti $\mathrm{F}_{\mathrm{A}}=42,36 \in D K_{A}=\{F \mid F>3,07\}$ sehingga $\mathrm{H}_{0 \mathrm{~A}}$ ditolak. Hal ini berarti terdapat perbedaan efek model pembelajaran Jigsaw, model pembelajaran GI dan model pembelajaran langsung. Karena terdiri dari tiga baris maka perlu dilakukan uji komparasi ganda antar baris. Rangkuman komparasi ganda antar baris disajikan pada Tabel 4

Tabel 4. Rangkuman Uji Lanjut Pasca Anava antar Baris

\begin{tabular}{cccl}
\hline $\mathrm{H}_{0}$ & $\mathrm{~F}_{\text {obs }}$ & $2 \mathrm{~F}_{0,05 ; 2 ; 255}$ & Keputusan \\
\hline$\mu_{1 .}=\mu_{2 .}$ & 11,99 & 6,14 & Ditolak \\
$\mu_{2 .}=\mu_{3 .}$ & 33,69 & 6,14 & Ditolak \\
$\mu_{1 .}=\mu_{3 .}$ & 85,12 & 6,14 & Ditolak \\
\hline
\end{tabular}

Pada uji komparasi ganda antar baris ke-1 dan baris ke-2 diperoleh $F_{1 \bullet-2 \bullet}=11.99$ dan $(2) \mathrm{F}_{0,05 ; 2,245}=6,14$, dan karena $F_{1 \bullet-2 \bullet}>(2) \mathrm{F}_{0,05 ; 2,245}$, sehingga $F_{1 \bullet-2 \bullet}$ $\in \mathrm{DK}$, yang berarti $\mathrm{H}_{0}$ ditolak. Dengan demikian berarti bahwa terdapat perbedaan rerata antara prestasi belajar matematika siswa pada siswa dengan model pembelajaran Jigsaw dan siswa dengan model pembelajaran GI. Berdasarkan rerata marginal antara prestasi 
belajar matematika siswa pada model pembelajaran Jigsaw dengan model pembelajaran GI menunjukkan bahwa rerata prestasi belajar matematika siswa pada model pembelajaran Jigsaw lebih tinggi daripada rerata prestasi belajar matematika siswa pada model pembelajaran GI, maka dapat disimpulkan bahwa prestasi belajar dimensi tiga pada siswa dengan model pembelajaran Jigsaw lebih baik daripada prestasi siswa dengan model pembelajaran GI. Pada uji komparasi ganda antar baris ke-2 dan baris ke-3 diperoleh $F_{2 \bullet-3 \bullet}=33,69$ dan $(2) \mathrm{F}_{0,05 ; 2,245}=6,14$, dan karena $F_{2 \bullet-3 \bullet}>(2) \mathrm{F}_{0,05 ; 2,245}$, sehingga $F_{2 \bullet-3 \bullet} \in \mathrm{DK}$, yang berarti $\mathrm{H}_{0}$ ditolak. Dengan demikian berarti bahwa terdapat perbedaan rerata antara prestasi belajar matematika siswa pada siswa dengan model pembelajaran GI dan siswa dengan model pembelajaran Langsung. Berdasarkan rerata marginal antara prestasi belajar matematika siswa pada model pembelajaran GI dengan model pembelajaran Langsung menunjukkan bahwa rerata prestasi belajar matematika siswa pada model pembelajaran GI lebih tinggi daripada rerata prestasi belajar matematika siswa pada model pembelajaran Langsung, maka dapat disimpulkan bahwa prestasi belajar dimensi tiga pada siswa dengan model pembelajaran GI lebih baik daripada prestasi siswa dengan model pembelajaran Langsung. Pada uji komparasi ganda antar baris ke-1 dan baris ke-3 diperoleh $F_{1 \bullet-3 \bullet}=85,12$ dan $(2) \mathrm{F}_{0,05 ; 2,245}=6,14$, dan karena $F_{1 \bullet-3 \bullet}>(2) \mathrm{F}_{0,05 ; 2,245}$, sehingga $F_{1 \bullet-3 \bullet} \in \mathrm{DK}$, yang berarti $\mathrm{H}_{0}$ ditolak. Dengan demikian berarti bahwa terdapat perbedaan rerata antara prestasi belajar matematika siswa pada siswa dengan model pembelajaran Jigsaw dan siswa dengan model pembelajaran Langsung. Berdasarkan rerata marginal antara prestasi belajar matematika siswa pada model pembelajaran Jigsaw dengan model pembelajaran Langsung menunjukkan bahwa rerata prestasi belajar matematika siswa pada model pembelajaran Jigsaw lebih tinggi daripada rerata prestasi belajar matematika siswa pada model pembelajaran Langsung, maka dapat disimpulkan bahwa prestasi belajar dimensi tiga pada siswa dengan model pembelajaran Jigsaw lebih baik daripada prestasi siswa dengan model pembelajaran Langsung.

Kesimpulan di atas sesuai dengan teori tentang model pembelajaran kooperatif tipe Jigsaw yang telah dijelaskan oleh Slavin (2009: 237). Model pembelajaran Jigsaw adalah salah satu model pembelajaran kooperatif yang lebih banyak melibatkan siswa dalam menelaah materi yang tercakup dalam suatu pelajaran dengan mengembangkan diskusi dan kerja kelompok. Siswa dituntut untuk saling kerjasama dan dapat melakukan diskusi dengan sungguh-sungguh, karena masing - masing siswa akan menjadi ahli dalam kelompoknya dan akan menjelaskan kepada anggota kelompoknya, sehingga 
mengakibatkan siswa akan menjadi lebih aktif dan cara ini menjamin keterlibatan total semua siswa. Model pembelajaran GI merupakan model pembelajaran kooperatif yang mencakup konsep penelitian (inquiry), pengetahuan (knowledge) dan dinamika belajar kelompok (the dynamics of the learninggroup). Akan tetapi pada saat berdiskusi terkadang cenderung didominasi oleh seseorang, karena ketika penyampaian laporan hasil diskusi hanya akan diwakilkan salah satu siswa pada setiap kelompok, sehingga mengakibatkan siswa yang lain menjadi pasif, sedangkan model pembelajaran langsung merupakan pembelajaran dengan menggunakan metode ceramah yang bervariasi, diselingi tanya jawab dan pemberian tugas atau pekerjaan rumah. Dalam model ini guru dituntut lebih banyak aktif daripada siswa. Karena pada model pembelajaran langsung guru lebih dominan, siswa cenderung pasif, kurang memperoleh kesempatan untuk mengembangkan kreativitasnya sehingga model pembelajaran ini tidak dapat menghasilkan prestasi belajar yang maksimal.

Berdasarkan hasil analisis variansi dua jalan dengan sel tak sama pada Tabel 2, untuk efek utama $B$ (kecerdasan emosional), nilai $F_{B}=58,60$ dan $F_{\alpha}=3,07$, berarti $\mathrm{F}_{\mathrm{B}}=58,60 \in D K_{B}=\{F \mid F>3,07\}$ sehingga $\mathrm{H}_{0 \mathrm{~B}}$ ditolak. Hal ini berarti terdapat perbedaan prestasi belajar matematika pada tingkat kecerdasan emosional tinggi, sedang maupun rendah. Karena terdiri dari tiga kolom maka perlu dilakukan uji komparasi ganda antar kolom. Rangkuman komparasi ganda antar kolom disajikan pada Tabel 5.

Tabel 5. Rangkuman Uji Lanjut Pasca Anava antar Kolom

\begin{tabular}{cccc}
\hline $\mathrm{H}_{0}$ & $\mathrm{~F}_{\mathrm{obs}}$ & $2 \mathrm{~F}_{0,05 ; 2 ; 255}$ & Keputusan \\
\hline$\mu_{.1}=\mu_{.2}$ & 9,44 & 6,14 & Ditolak \\
$\mu_{.2}=\mu_{.3}$ & 60,97 & 6,14 & Ditolak \\
$\mu_{.1}=\mu_{.3}$ & 111,39 & 6,14 & Ditolak \\
\hline
\end{tabular}

Pada uji komparasi ganda antar kolom ke-1 dan kolom ke-2 diperoleh $F_{\bullet \mathbf{\bullet} \bullet 2}=9,44$ dan $(2) \mathrm{F}_{0,05 ; 2,245}=6,14$, dan karena $F_{\bullet 1-\bullet 2}>(2) \mathrm{F}_{0,05 ; 2,245}$, sehingga $F_{\bullet \mathbf{\bullet}-\bullet 2}$ $\in \mathrm{DK}$, yang berarti $\mathrm{H}_{0}$ ditolak. Dengan demikian berarti bahwa terdapat perbedaan rerata antara prestasi belajar matematika siswa dengan kecerdasan emosional rendah dan sedang. Berdasarkan rerata marginal antara prestasi belajar matematika siswa dengan kecerdasan emosional rendah dan sedang menunjukkan bahwa rerata prestasi belajar matematika siswa dengan kecerdasan emosional sedang lebih tinggi daripada rerata prestasi belajar matematika siswa dengan kecerdasan emosional rendah, maka dapat disimpulkan bahwa prestasi belajar matematika siswa yang memiliki kecerdasan emosional sedang lebih baik daripada prestasi belajar matematika siswa yang memiliki kecerdasan emosional rendah. Pada uji komparasi ganda antar kolom ke-2 dan kolom ke3 diperoleh $F_{\bullet 2-\bullet 3}=60,97$ dan $(2) \mathrm{F}_{0,05 ; 2,245}=6,14$, dan karena $F_{\bullet 2-\bullet 3}>(2) \mathrm{F}_{0,05 ; 2,245}$, 
sehingga $F_{\bullet 2-\bullet 3} \in \mathrm{DK}$, yang berarti $\mathrm{H}_{0}$ ditolak. Dengan demikian berarti bahwa terdapat perbedaan rerata antara prestasi belajar matematika siswa dengan kecerdasan emosional sedang dan tinggi. Berdasarkan rerata marginal antara prestasi belajar matematika siswa dengan kecerdasan emosional sedang dan tinggi menunjukkan bahwa rerata prestasi belajar matematika siswa dengan kecerdasan emosional tinggi lebih tinggi daripada rerata prestasi belajar matematika siswa dengan kecerdasan emosional sedang, maka dapat disimpulkan bahwa prestasi belajar matematika siswa yang memiliki kecerdasan emosional tinggi lebih baik daripada prestasi belajar matematika siswa yang memiliki kecerdasan emosional sedang. Pada uji komparasi ganda antar kolom ke-1 dan kolom ke3 diperoleh $F_{\bullet 1-\bullet 3}=60,97$ dan $(2) \mathrm{F}_{0,05 ; 2,245}=6,14$, dan karena $F_{\bullet 1-\bullet 3}>(2) \mathrm{F}_{0,05 ; 2,245}$, sehingga $F_{\bullet 1-\bullet} \in \mathrm{DK}$, yang berarti $\mathrm{H}_{0}$ ditolak. Dengan demikian berarti bahwa terdapat perbedaan rerata antara prestasi belajar matematika siswa dengan kecerdasan emosional rendah dan tinggi. Berdasarkan rerata marginal antara prestasi belajar matematika siswa dengan kecerdasan emosional rendah dan tinggi menunjukkan bahwa rerata prestasi belajar matematika siswa dengan kecerdasan emosional tinggi lebih tinggi daripada rerata prestasi belajar matematika siswa dengan kecerdasan emosional rendah, maka dapat disimpulkan bahwa prestasi belajar matematika siswa yang memiliki kecerdasan emosional tinggi lebih baik daripada prestasi belajar matematika siswa yang memiliki kecerdasan emosional rendah.

Kecerdasan emosional sangat diperlukan dalam memenuhi harapan atau pencapaian tujuan, termasuk dalam pembelajaran kooperatif. Goleman (2009) menyebutkan bahwa seseorang mempunyai dua otak, dua pikiran dan dua jenis kecerdasan yang berlainan yaitu kecerdasan rasional dan kecerdasan emosional. Keberhasilan seseorang tidak hanya ditentukan oleh IQ, tetapi juga ditentukan oleh kecerdasan emosional. Intelektualitas tidak dapat bekerja sebaik-baiknya tanpa kecerdasan emosional. Sedangkan menurut Slameto (1998) keberhasilan siswa dalam mencapai prestasi belajar salah satunya ditentukan faktor intelegensi (kecerdasan) dan salah satu kecerdasan seseorang adalah kecerdasan emosional. Siswa yang mempunyai tingkat kecerdasan emosional tinggi mempunyai kemampuan mengenali emosi diri sendiri, penilaian diri secara teliti, rasa percaya diri, cenderung optimis, memiliki komitmen, memiliki dorongan berprestasi, memotivasi diri sendiri, mengenali emosi orang lain, keterampilan bergaul, memiliki semangat, berketekunan tinggi serta keterampilan berinteraksi dengan sesama siswa dan guru dalam proses belajar. Dengan adanya tingkat kecerdasan emosional yang tinggi akan berdampak pada pencapaian prestasi yang tinggi pula. Sehingga siswa yang mempunyai kecerdasan emosional lebih 
tinggi prestasi belajarnya lebih baik daripada siswa yang mempunyai kecerdasan emosional rendah.

Berdasarkan hasil analisis variansi dua jalan dengan jumlah sel tak sama pada Tabel 2 diperoleh nilai uji $F_{a b}=4,31$ dan $F_{\text {tabel }}=2,45$, sehingga nilai $F_{a b}=4,31>F_{\text {tabel }}$ $=2,45$. Hal ini berarti terdapat interaksi antara model pembelajaran dengan kecerdasan emosional siswa, maka perlu dilakukan uji lanjut pasca anava antar sel pada kolom yang sama yang disajikan pada Tabel 6 .

Tabel 6. Rangkuman Uji Lanjut Pasca Anava Antar Sel pada Kolom yang Sama

\begin{tabular}{cccc}
\hline $\mathrm{H}_{0}$ & $\mathrm{~F}_{\text {obs }}$ & $8 \mathrm{~F}_{0,05 ; 8 ; 255}$ & Keputusan \\
\hline$\mu_{11}=\mu_{21}$ & 2,19 & 16,16 & Tidak ditolak \\
$\mu_{21}=\mu_{31}$ & 0,64 & 16,16 & Tidak ditolak \\
$\mu_{11}=\mu_{31}$ & 5,67 & 16,16 & Tidak ditolak \\
$\mu_{12}=\mu_{22}$ & 8,43 & 16,16 & Tidak ditolak \\
$\mu_{22}=\mu_{32}$ & 8,05 & 16,16 & Tidak ditolak \\
$\mu_{12}=\mu_{32}$ & 33,19 & 16,16 & Ditolak \\
$\mu_{13}=\mu_{23}$ & 8,78 & 16,16 & Tidak ditolak \\
$\mu_{23}=\mu_{33}$ & 26,97 & 16,16 & Ditolak \\
$\mu_{13}=\mu_{33}$ & 60,32 & 16,16 & Ditolak \\
\hline
\end{tabular}

Selanjutnya dari uji lanjut pasca anava diperoleh $\mathrm{DK}=\{\mathrm{F} \mid \mathrm{F}>16,16\}$ dan berdasarkan data yang ada pada rataan masing-masing sel, uji anava dua jalan sel tak sama dan uji lanjut pasca anava diperoleh kesimpulan pada siswa yang tingkat kecerdasan emosionalnya rendah penggunaan model pembelajaran Jigsaw, GI dan langsung memberikan prestasi belajar matematika yang sama. Hal ini disebabkan siswa yang memiliki tingkat kecerdasan emosional rendah tidak suka berdiskusi atau kerja kelompok, kurang dalam memotivasi dirinya sendiri, memiliki semangat yang rendah dalam pembelajaran, mempunyai ketekunan yang rendah, tidak memiliki keberanian untuk bertanya dan mengungkapkan pendapat, serta kurang mampu berinteraksi dengan sesama teman dan guru. Sehingga ketiga model pembelajaran ini tidak akan mempengaruhi prestasi belajarnya. Pada siswa yang tingkat kecerdasan emosionalnya sedang, penggunaan model pembelajaran Jigsaw dan GI memberikan prestasi belajar matematika yang sama, GI dan langsung memberikan prestasi belajar matematika yang sama. Jigsaw memberikan prestasi belajar matematika lebih baik daripada langsung. Pada siswa yang tingkat kecerdasan emosionalnya tinggi, penggunaan model pembelajaran Jigsaw dan GI memberikan prestasi belajar matematika yang sama, GI memberikan prestasi belajar matematika yang lebih baik daripada langsung, Jigsaw memberikan prestasi belajar matematika yang lebih baik daripada langsung. Pada siswa yang kecerdasannya sedang dan tinggi hasil penelitian ini tidak sesuai dengan hipotesis. Ketidaksesuaian antara hasil penelitian ini dengan hipotesis menurut penulis ada beberapa kemungkinan penyebabnya diantaranya, adanya beberapa siswa yang tingkat kecerdasan 
emosionalnya sedang dan tinggi menjelang tes uji prestasi dimensi tiga ditugaskan oleh sekolah untuk latihan karnaval dalam rangka HUT Wonogiri yang ke 272, sehingga siswa-siswa tersebut kurang konsentrasi dalam mengerjakan tes uji prestasi tersebut.

Berdasarkan hasil analisis variansi dua jalan dengan jumlah sel tak sama pada Tabel 2 diperoleh nilai uji $F_{a b}=4,31$ dan $F_{\text {tabel }}=2,45$, sehingga nilai $F_{a b}=4,31>F_{\text {tabel }}$ $=2,45$. Hal ini berarti terdapat interaksi antara model pembelajaran kooperatif dengan Kecerdasan Emosional siswa, maka perlu dilakukan uji lanjut pasca anava antar sel pada baris yang sama yang disajikan pada Tabel 7 .

Tabel 7. Rangkuman Uji Lanjut Pasca Anava Antar Sel pada baris yang sama

\begin{tabular}{cccc}
\hline $\mathrm{H}_{0}$ & $\mathrm{~F}_{\text {obs }}$ & $8 \mathrm{~F}_{0,05 ; 8 ; 255}$ & Keputusan \\
\hline$\mu_{11}=\mu_{12}$ & 11,47 & 16,16 & Tidak ditolak \\
$\mu_{12}=\mu_{13}$ & 25,38 & 16,16 & Ditolak \\
$\mu_{11}=\mu_{13}$ & 69,31 & 16,16 & Ditolak \\
$\mu_{21}=\mu_{22}$ & 4,05 & 16,16 & Tidak ditolak \\
$\mu_{22}=\mu_{23}$ & 27,88 & 16,16 & Ditolak \\
$\mu_{21}=\mu_{23}$ & 48,61 & 16,16 & Ditolak \\
$\mu_{31}=\mu_{32}$ & 0,05 & 16,16 & Tidak ditolak \\
$\mu_{32}=\mu_{33}$ & 6,91 & 16,16 & Tidak ditolak \\
$\mu_{31}=\mu_{33}$ & 7,56 & 16,16 & Tidak ditolak \\
\hline
\end{tabular}

Selanjutnya dari uji lanjut pasca anava diperoleh $\mathrm{DK}=\{\mathrm{F} \mid \mathrm{F}>16,16\}$ dan berdasarkan data yang ada pada rataan masing-masing sel, uji anava dua jalan sel tak sama dan uji lanjut pasca anava diperoleh kesimpulan sebagai berikut. Pada siswa yang dikenai model pembelajaran Jigsaw; prestasi belajar matematika siswa yang tingkat kecerdasan emosionalnya rendah dan sedang sama, prestasi belajar matematika siswa yang tingkat kecerdasan emosionalnya tinggi lebih baik daripada siswa yang tingkat kecerdasan emosionalnya sedang dan rendah. Pada siswa yang dikenai model pembelajaran GI; prestasi belajar matematika siswa yang tingkat kecerdasan emosionalnya rendah dan sedang sama, prestasi belajar matematika siswa yang tingkat kecerdasan emosionalnya tinggi lebih baik daripada siswa yang tingkat kecerdasan emosionalnya sedang dan rendah. Pada siswa yang dikenai model pembelajaran Jigsaw dan GI hasil penelitian ini tidak sesuai dengan hipotesis. Ketidaksesuaian antara hasil penelitian ini dengan hipotesis menurut penulis ada beberapa kemungkinan penyebabnya diantaranya, adanya beberapa siswa yang tingkat kecerdasan emosionalnya sedang dan tinggi menjelang tes uji prestasi dimensi tiga ditugaskan oleh sekolah untuk latihan karnaval dalam rangka HUT Wonogiri yang ke 272, sehingga siswa-siswa tersebut kurang konsentrasi dalam mengerjakan tes uji prestasi tersebut. Pada siswa yang dikenai model pembelajaran langsung, prestasi belajar matematika siswa yang tingkat kecerdasan emosionalnya rendah, sedang dan tinggi sama. Hal ini sesuai dengan hipotesis, karena model pembelajaran langsung merupakan model pembelajaran yang menggunakan 
metode ceramah yang bervariasi, diselingi tanya jawab dan pemberian tugas atau pekerjaan rumah. Dalam model ini guru dituntut lebih banyak aktif daripada siswa. Karena pada model pembelajaran langsung guru lebih dominan, maka siswa cenderung pasif, kurang memperoleh kesempatan untuk menngembangkan kreativitasnya. Dengan demikian pembelajaran langsung dipandang tidak sesuai dengan pembelajaran kooperatif yang berdasarkan konstruktivisme, sehingga penggunaan model pembelajaran langsung tidak ada pengaruhnya terhadap siswa yang tingkat kecerdasan emosionalnya rendah, sedang maupun tinggi.

\section{KESIMPULAN DAN SARAN}

Berdasarkan hasil penelitian dan analisis data dapat ditarik kesimpulan sebagai berikut.

1. Penggunaan model pembelajaran Jigsaw menghasilkan prestasi belajar matematika yang lebih baik daripada penggunaan model pembelajaran GI maupun langsung, penggunaan model pembelajaran GI menghasilkan prestasi belajar matematika yang lebih baik daripada pembelajaran langsung.

2. Prestasi belajar matematika siswa yang memiliki kecerdasan emosional tinggi lebih baik daripada prestasi siswa yang memiliki kecerdasan emosional sedang maupun rendah, siswa yang memiliki kecerdasan emosional sedang lebih baik daripada prestasi siswa yang memiliki kecerdasan emosional rendah.

3. Siswa yang kecerdasan emosionalnya rendah, penggunaan model pembelajaran Jigsaw, GI dan langsung memberikan prestasi belajar yang sama. Siswa yang kecerdasan emosionalnya sedang, penggunaan model pembelajaran Jigsaw memberikan prestasi belajar yang sama dengan model pembelajaran GI, penggunaan model pembelajaran GI sama dengan model pembelajaran langsung, penggunaan model pembelajaran Jigsaw memberikan prestasi belajar yang lebih baik daripada model pembelajaran langsung. Siswa yang kecerdasan emosionalnya tinggi, penggunaan model pembelajaran Jigsaw memberikan prestasi belajar yang sama dengan GI, penggunaan model pembelajaran GI memberikan prestasi belajar yang lebih baik daripada pembelajaran langsung, penggunaan model pembelajaran Jigsaw memberikan prestasi belajar yang lebih baik daripada pembelajaran langsung.

4. Siswa yang dikenai model pembelajaran Jigsaw, kecerdasan emosional rendah dan sedang prestasi belajarnya sama, kecerdasan emosional tinggi prestasi belajarnya lebih baik daripada kecerdasan emosional sedang maupun rendah. Siswa yang dikenai model pembelajaran GI, kecerdasan emosional rendah dan sedang prestasi belajarnya sama, kecerdasan emosional tinggi prestasi belajarnya lebih baik daripada 
kecerdasan emosional sedang maupun rendah. Siswa yang dikenai model pembelajaran langsung, kecerdasan emosional rendah, sedang maupun tinggi prestasi belajarnya sama.

Berdasarkan kesimpulan di atas, beberapa saran yang dapat disampaikan sebagai berikut:

1. Guru matematika hendaknya mau menerapkan model pembelajaran kooperatif tipe Jigsaw dan GI sebagai alternatif dalam pembelajaran matematika khususnya pada materi dimensi tiga, karena model pembelajaran kooperatif tipe Jigsaw dan GI samasama merupakan suatu model pembelajaran yang berorientasi pada proses, sehingga pembelajaran lebih bermakna dan dapat lebih meningkatkan pemahaman siswa terhadap suatu materi pelajaran.

2. Guru matematika hendaknya mengetahui tingkat kecerdasan emosional setiap siswanya dan menerapkan model pembelajaran yang sesuai dengan tingkat kecerdasan emosional tersebut, karena keberhasilan suatu pembelajaran salah satunya dipengaruhi oleh kecerdasan emosional.

\section{DAFTAR PUSTAKA}

Ballantine, J., dan Larres, P. 2007. Cooperative learning: A Pedagogy to Improve Students Generic Skills, Journal Articles; Reports- Evaluative.Education \& Training, v49, n2, p126-137.

Tan, I.G.C, Eng L.C.K And Shlomo, S. 2007. "Group Investigation Effects on Achievement, Motivation, and Perceptions of Students in Singapore". The Journal of Educational Research, Volume 100 Number 3 Page 142-154.

Goleman,D.2009. Emotional Intelligence : mengapa EI lebih penting dari IQ.: PT.Gramedia Pustaka Utama. Jakarta.

Puspendik Balitbang Kemendikbud BNSP. 2012. Laporan Hasil Ujian Nasional SMA/MA Tahun Pelajaran 2011/2012. : Kemendikbud. Jakarta.

Slameto. 2003. Belajar dan Faktor-faktor yang Mempengaruhinya. : Rineka Cipta. Jakarta.

Slavin, R.E. 2009. Cooperative Learning. : Nusa Media. Bandung.

Sugiyanto. 2008. Model-Model Pembelajaran Interaktif, : Panitia Sertifikasi Guru (PSG) Rayon 13. Surakarta. 